\title{
Determinants of Chinese Tourists' Loyalty to Korea: A Comparison of Film and Non-film Tourist Perceptions
}

\author{
Weisheng Chiu and Shiheng Zeng
}

\begin{abstract}
The aims of this study were to investigate the influences of destination image, place attachment and satisfaction on Chinese tourists' loyalty and compare the differences between film and non-film tourists. The results revealed that film tourists have significant higher values of cognitive image, place identity, place dependence, social bonding, satisfaction and tourist loyalty. As for the determinant factors of Chinese tourists' loyalty to Korea, the social bonding and satisfaction significantly predict to film tourists' loyalty; whereas the affective image, place dependence, social bonding and satisfaction significantly lead to non-film tourists' loyalty. The findings of the study contribute to the understanding of Chinese tourists' perceptions and behaviors. Moreover, the implications for film and destination marketers were also discussed.
\end{abstract}

Index Terms-Destination image, place attachment, revisit intention, satisfaction, film tourist.

\section{INTRODUCTION}

Korean TV dramas/movies are popular in Asian countries and have influenced the development of Republic of Korea (hereafter referred to as Korea) as an international film-induced tourism destination [1], [2]. In China, there was a fever created by a Korean TV drama series titled "My love from the stars" in the beginning of 2014, which caused a variety of economic and socio-cultural impacts. This craze is also known as Korean wave which defined as the content of Korean popular culture including television dramas, movies, popular songs and their associated celebrities [3]. It also has played a significant role in attracting tourists all over the world [1].

China, as a neighbor country of Korea, is greatly influence by the Korean TV dramas/movies. The wave of Korean TV dramas and movies has been popular in China, and as such, enhanced the Chinese residents' understanding of Korean culture [2], [4]. Consequently, there has been an increasing amount of Chinese tourists visiting Korea in the recent years. China has been the largest market for Korea tourism since 2013 [5]. According to the report of Korean Tourism Organization, in 2014, over 6 million Chinese tourists visited Korean, representing $43.1 \%$ of the total foreign tourists, and the percentage of Chinese tourists among total inbound tourists to Korea has drastically increased $327 \%$ from 2010 to 2014 [5]. For Chinese tourists, Korea has become one of the major destination choices [1].

Manuscript received March 20, 2015; revised July 2, 2015.

The authors are with the Department of Sport and Leisure Studies, Yonsei University, Seoul, Republic of Korea (e-mail: weishengchiu@yonsei.ac.kr, zengshiheng@hotmail.com)
Despite the unique phenomenon of Korean wave and the increasing tourist flows from China to Korea, relatively little research has been explored the loyalty of Chinese tourists toward Korea as a destination. Thus, in order to understand Chinese tourists' perceptions comprehensively, the aims of this study were to investigate the impact of destination image, place attachment and satisfaction on Chinese tourists' loyalty to Korea and compare these perceptions between Film and non-film tourists visiting Korea.

\section{LITERATURE REVIEW}

\section{A. Film-Induce Tourism}

The term of film-induced tourism is a relatively new concept in tourism research [6]-[8]. Film-induced tourism refers to visitation to sites where movies and TV programs have been filmed as well as tours to production studios, including film-related theme parks, film premier attendance, award ceremonies, film festivals, celebrity spotting [9]-[12]. Researchers have verified that tourists are more like to visit the places where shown in the films/drams [13], [14]. Reference [15] also argued that films and television shows are perceived to be more reliable and trustworthy - as are other mass media sources - than biased promotions and advertisements, and as such, they stand a better chance of influencing destination images.

Researchers have proposed different types of film tourists based on their travel purpose. Reference [16] categorized tourists into "film and non-film tourists". Film tourists are those who are traveling to a film/drama site as part of their itinerary during their trip. However, non-film tourists are those who are the general tourists without the purpose of visiting a film/drama site [16], [17]. In the current study context, in order to compare the differences between film and non-film tourists, Chinese tourists were divided into film tourists and non-film tourists.

\section{B. Tourist Loyalty}

In the tourism literature, tourist loyalty is a one of the most important behavioral outcomes to assess tourist behaviors [18]. In the review of literature, the degree of tourist loyalty to a destination is reflected in their intentions to revisit the destination and in their willingness to recommend it [18]. Repeat visitors represent a critical market segment for many tourism destinations as they are more like to stay longer at a destination than the first-time visitors, tend to spread positive information through word of mouth (WOM), and participate in consumptive activities more intensively [19]. Moreover, this kind of repeating visitors can reduce lower marketing cost than attracting first time visitors [20]. 
There are many factors influencing tourist loyalty to a destination. In the review of literature, it revealed that destination image, placement attachment, and satisfaction are the critical predictors to tourist loyalty to a destination [21], [22]. Thus, these determinants of tourist loyalty were discussed in the following sections.

\section{Destination Image}

Destination image is one of the most important determinants of tourists' pre-, in situ, and post-purchase decisions and travel behaviors [23]-[25]. The definitions of destination image generally focus on an individual's overall perception toward a place (e.g, Baloglu \& McCleary, 1999). However, destination image is not a one-dimensional construct but a multifaceted concept consisting of cognitive and affective components. Cognitive image was regarded as the evaluation of the known attributes of the destination [26], [27], [28]. Affective image refers to an individual's emotion and feelings about the destination [26]. Consistent with these definitions, studies on cognitive image have focused on the evaluation of physical attributes of places. On the other hand, affective image focuses on emotional responses to places and environmental features [29].

\section{Placement Attachment}

A large amount of studies have explored the nature of people's emotional relationship with places, including their interactions with social groups [30]. The definition of placement attachment is the emotional bond between an individual and a particular spatial setting [31]. Reference [32] proposed an overarching concept of place attachment, consisting of place identity, place dependence and social bonding. Place identity denotes to the cognitive and affective connection between an individual identity and a place. Place dependence is described as visitors' functional attachment to a specific destination and their consciousness of the uniqueness of a setting. Social boning is the interpersonal relationships and experience occurred in specific settings [32], [33]. Taken together, the multivalent nature of place illustrates cultivation of place attachment through identity, dependence, and the socially-shared experiences associated with the place.

\section{E. Satisfaction}

Satisfaction is the central concept in the tourism literature. Satisfaction can be seen as a tourist's post-purchase evaluation of the destination [34]. In tourism research, Reference [35] argued that satisfaction is not only the pleasurableness of the experience but also the evaluation rendered that the experience was at least as good as it was supposed to be. Hence, the central tenet of visitor satisfaction measurement in tourism literature has been focused on disconfirmation theory [36], satisfaction evokes when consumers compare their initial expectations with their perceptions. Once perceived experience is greater than expectations, the consumer is satisfied [36].

\section{METHOD}

\section{A. Participants and Procedure}

Data were collected by using convenience sampling method. The survey was carried out to Chinese tourists at the popular tourist sites in Seoul City, such as Myeongdong, Seoul Tower, and Dongdaemun. Finally, 350 copies of the questionnaire were distributed. After eliminating invalid responses, a total of 311 completed questionnaires were consequently collected for further analyses.

\section{B. Measures}

The survey instruments included four sections. First, the Destination image scale consists of two dimensions: Seven items for cognitive image [21] and four items for affective image [37]. The thee-dimensional 12-item scale of place attachment was adopted from Reference [32]. Satisfaction (3 items) and revisit intention (3 items) were taken from Reference [38]. Furthermore, the original English version of the questionnaire was translated into a Chinese version based on Back-translation approach [39]. All scale items were evaluated with a five-point Likert scale ranging from (1), strongly disagree, to (7) strongly agree.

As the next step, a confirmatory factor analysis was performed to assess the measurement model, including the examination of construct reliability and convergent and discriminate validity. The measurement model fulfilled the criteria suggested by Reference [40], and yielded an acceptable level of model fit, $\chi 2=(356)=1070.08$, CFI $=.91$, TLI $=.90$, RMSEA $=.08$. The reliability of the constructs was evaluated by composite reliability analysis. It was observed that all the values exceeded the recommended cut-off value of 0.60 [41]. Moreover, the factor loadings of the construct items and the values of average variance extracted are all above 0.50 , indicating good convergent validity for each of the construct items [42]. Discriminant validity is established when the AVEs of a construct exceed the shared variances between the construct in the model [43].

\section{Data Analysis}

The current study uses the SPSS 18.0 statistical package for the data analysis in three sections. First, a descriptive analysis was evaluated for the sample structure. Second, an independent sample t-test was conducted to examine the differences of perceptions between film and non-film tourists. Finally, a multiple regression model across two groups was applied to identify the determinants of Chinese tourists' loyalty to Korea.

\section{RESUlTS}

As reported in Table I, the results of descriptive the sample of 311 visitors consisted of $42.4 \%$ film tourists $(n=132)$ and $57.6 \%$ non-film tourists $(n=179)$. For film tourists, most of them were female $(n=107,81.1 \%)$ and between 20 to 29 years old $(n=67,50.8 \%)$. Their income is mainly between RMB 3,000-5,000 (US\$1 $\fallingdotseq$ RMB6.2). Most of them were first time to visit Korea $(n=78,59.1 \%)$ and stay for 3 to 6 days $(n=98,74.2 \%)$. In terms of non-film tourists, females were slightly more males, and age was mainly between 20 to 39 years old $(n=146,81.5 \%)$. Their income is mostly over RMB 10,000 (US\$1 $\fallingdotseq$ RMB6.2). Most of them were first time to visit Korea $(n=115,64.3 \%)$ and stay for 3 to 6 days ( $n$ $=125,69.8 \%$ ). 
TABLE I: DEMOGRAPHIC PROFILE OF RESPONDENTS

\begin{tabular}{|c|c|c|}
\hline & $\begin{array}{c}\text { Film-tourists } \\
\quad(n=132)\end{array}$ & $\begin{array}{c}\text { Non-film tourists } \\
(n=179)\end{array}$ \\
\hline & Number (\%) & Number (\%) \\
\hline \multicolumn{3}{|l|}{ Gender } \\
\hline Male & $25(18.9)$ & $86(48)$ \\
\hline Female & $107(81.1)$ & $93(52)$ \\
\hline \multicolumn{3}{|l|}{ Age } \\
\hline 20-29 & $67(50.8)$ & $74(41.3)$ \\
\hline $30-39$ & $36(27.3)$ & $72(40.2)$ \\
\hline $40-49$ & $18(13.6)$ & $29(11.2)$ \\
\hline More than 50 & $11(8.3)$ & $13(7.3)$ \\
\hline \multicolumn{3}{|l|}{ Income (RMB) } \\
\hline$<3000$ & $30(22.7)$ & $17(9.5)$ \\
\hline $3000-5000$ & $42(31.8)$ & $48(26.8)$ \\
\hline $5000-10000$ & $33(25.0)$ & $53(29.6)$ \\
\hline$>10000$ & $27(20.5)$ & $61(34.1)$ \\
\hline \multicolumn{3}{|l|}{ Past experience } \\
\hline First-time visit & $78(59.1)$ & $115(64.3)$ \\
\hline Repeated visit & $54(40.9)$ & $64(35.7)$ \\
\hline \multicolumn{3}{|c|}{ Length of stay (days) } \\
\hline $1-3$ & $11(8.4)$ & $19(10.6)$ \\
\hline $3-6$ & $98(74.2)$ & $125(69.8)$ \\
\hline More than 6 & $23(17.4)$ & $35(19.6)$ \\
\hline
\end{tabular}

Second, an independent sample t-test was used to test whether differences existed between the two tourists groups in their evaluation of destination image, place attachment, satisfaction, and tourist loyalty. As illustrated in Table II, the differences of Chinese tourists' perceptions between film and non-film tourists were found. Film tourists have significant higher values of cognitive image, place identity, place dependence, social bonding, satisfaction, and tourist loyalty, whereas there was no significant difference in affective image between film and non-film tourists.

TABLE II: THE DIFFERENCES BETWEEN FILM AND NON-FILM TOURISTS

\begin{tabular}{lcccc}
\hline \hline \multirow{2}{*}{ Constructs } & $\begin{array}{c}\text { Total tourists } \\
(\mathrm{N}=311)\end{array}$ & $\begin{array}{c}\text { Film tourists } \\
(n=132)\end{array}$ & $\begin{array}{c}\text { Non-film } \\
\text { tourists } \\
(n=179)\end{array}$ & \multirow{2}{*}{$t$ value } \\
\cline { 2 - 4 } & Mean (SD) & Mean (SD) & Mean (SD) & \\
\hline Destination image & & & & \\
Cognitive image & $5.32(1.04)$ & $5.48(1.05)$ & $5.20(1.01)$ & $2.38^{*}$ \\
Affective image & $5.09(1.17)$ & $5.22(1.22)$ & $4.99(1.13)$ & 1.72 \\
Place attachment & & & & \\
Place identity & $4.62(1.45)$ & $4.95(1.45)$ & $4.38(1.40)$ & $3.47 * * *$ \\
Place dependence & $4.23(1.62)$ & $4.58(1.62)$ & $3.98(1.57)$ & $3.30 * * *$ \\
Social bonding & $5.02(1.40)$ & $5.31(1.36)$ & $4.81(1.40)$ & $3.21 * * *$ \\
Satisfaction & $5.32(1.21)$ & $5.57(1.25)$ & $5.15(1.16)$ & $3.08 * *$ \\
Tourist loyalty & $5.33(1.49)$ & $5.57(1.41)$ & $5.16(1.52)$ & $2.41 *$ \\
\hline \hline$* p<.05, * * p<.01, * * * p<.001$ & & &
\end{tabular}

Finally, multiple regression analyses across film and non-film groups were performed to investigate the influence of destination image, place attachment, and satisfaction on Chinese tourists' loyalty (see Table III). Preliminary analysis was conducted to ensure no violation of the assumptions of multi-collinearity. Tolerance and Variance Inflation Factor (VIF) for variables were more than 0.10 and less than 10 respectively [44]. In the model 1 of film tourists, the total variance explained by the model was $60.6 \%, \mathrm{~F}(6,125)=$ $34.52, p<0.001$. The analysis showed that social bonding $(\beta$ $=0.44, p<0.001)$ and satisfaction $(\beta=0.30, p<0.01)$ predict tourist loyalty. In the model 1 of non-film tourists, the total variance explained by the model was $66.7 \%, \mathrm{~F}(6,172)=$ $60.42, p<0.001$. The analysis showed that affective image $(\beta$ $=0.12, p<0.05)$, place attachment $(\beta=0.24, p<0.01)$, social bonding $(\beta=0.34, p<0.001)$ and satisfaction $(\beta=0.18, p<$ $0.05)$ predict tourist loyalty.

TABLE III: MULTIPLE REGRESSION ANALYSIS

\begin{tabular}{lcc}
\hline \hline & $\begin{array}{c}\text { Model } 1 \\
\text { Film tourists } \\
(n=132)\end{array}$ & $\begin{array}{c}\text { Model 2 } \\
\text { Non-film tourists } \\
(n=179)\end{array}$ \\
\hline Cognitive image & .04 & .03 \\
Affective image & -.06 & $.12 *$ \\
Place identity & .050 & .04 \\
Place dependence & .10 & $.24 * *$ \\
Social bonding & $.44 * * *$ & $.34 * * *$ \\
Satisfaction & $.30 * *$ & $.18 *$ \\
\hline \hline$* p<.05, * * p<.01, * * * p<.001$ & \\
\end{tabular}

\section{DisCUSSION AND LIMITATIONS}

\section{A. Discussion and Implications}

This study evaluated the determinants of Chinese tourists' loyalty to Korea including destination image, place attachment, satisfaction, and loyalty and investigated the differences between two types of tourist: film and non-film tourists. According to the findings of this research, the following remarks can be made.

First, it is obvious that the characteristics of film and non-film tourists are dissimilar. Because of younger audience of Korea films/dramas, it shows that film tourists are dominated by male between the ages of 20-29 with lower income level, consistent with the the report of Reference [45]. At the same time, it reveals that male visitors are both relative fewer than male visitors and elder tourists are rare to see among film and non-film tourists. It indicates that Korea may be a more popular destination for the female tourists of younger generation. This may attribute to popularity of Korean wave and therefore people generally perceive the vigorous and energetic image of Korea [3]. Designation managers should cultivate younger generation and meanwhile develop the potential visitors of elder generation.

Second, it should be noted that film tourists have higher level of all the perceptions than non-film tourists do except for affective image. These findings indicate that film tourists recognize better attributes of Korea as a destinations which can be functional/ tangible (e.g. accommodation, cultural attractions) and psychological/abstract (e.g. friendly, atmosphere). Moreover, it is not surprising that film tourists show stronger psychological attachment to Korea. Film tourists have seen the Korean movies/drams and established emotional connection to the destination before visiting Korea. Meanwhile, film tourists are more likely to be satisfied their trip to Korea and developing their loyalty, including revisit a destination, as well as spread positive world - of -mouth. This type of tourists may play a critical important role in the development of Korea tourism industry because they not only have higher possibility to revisit Korea but also recommend their friends or other people to travel in Korea. Destination 
managers should cooperate with film/drama producers to design more elaborate promotion strategies for attracting potential visitors. All the audiences of Korea films/dramas could be the future tourists to Korea.

Third, the findings show that the significant determinants of Chinese tourist loyalty are discrepant between film and non-film tourists. For both groups, social bonding and satisfaction are important for explaining their loyalty. It is consistent with the argument of previous studies [22], [37], indicating significance of pleasurable feelings and emotional connection in building loyalty. However, affective image and place dependence play a greater role in explaining loyalty among non-film tourists. For non-film tourists, they have less understanding about Korea as a destination. Therefore, the emotional experience (i.e., affective image) during the trip may be valued as the reference for future behaviors. Place dependence reflects the importance of a resource in providing required services for desired recreational activities and is embodied in the physical characteristics of a setting. This tangible experience also determines their loyalty to a destination. Although film tourists may inherently be more ardent to a destination, how to build the loyalty of non-film tourists is an important issue for destination managers.

\section{B. Limitations}

Although the findings of this study contribute to the understanding of the determinants of Chinese tourists' loyalty in Korea, there are still some limitations in this study. First, we conducted a convenience sampling method; therefore, the results may not be construed as representative of all parts of Chinese tourists. The future can collect the sample with more diverse profile of Chinese tourists to generalize the results of this study. Second, only structured questions were operated in this study. In order to better understand about Chinese tourists' deeper personal experience toward Korea, future studies can conduct a qualitative method or a mixed method to investigate the subtle shade of tourists' perceptions. Finally, the current study only focused on the variables of destination image, place attachment, satisfaction, and loyalty. For a more comprehensive view of determinants of tourist loyalty, variables such as place attachment, perceived value, or personal involvement should be taken into consideration in future research.

\section{REFERENCES}

[1] S. Kim, P. Long and M. Robinson, "Small screen, big tourism: The role of popular Korean television dramas in South Korean Tourism," Tourism Geographies, vol. 11, no. 3, pp. 308-333, 2009.

[2] H. J. Su, Y-A. Huang, G. Brodowsky, and H. J. Kim, "The impact of product placement on TV-induced tourism: Korean TV dramas and Taiwanese viewers," Tourism Management, vol. 32, no. 4, pp. 805-814, 2011.

[3] B. H. Chua and K. Iwabuchi, East Asian Pop Culture: Analysing the Korean Wave, Hong Kong: Hong Kong University Press, 2008.

[4] S. S. Kim, J. Agrusa, K. Chon, and Y. Cho, "The effects of Korean pop culture on Hong Kong residents' perceptions of Korea as a potential tourist destination," Journal of Travel \& Tourism Marketing, vol. 24, no. 2- 3, pp.163-183, 2008.

[5] Korea Tourism Organization. (2014). Tourism statistics. [Online]. Available:

http://kto.visitkorea.or.kr/kor/notice/data/statis/profit/board/view.kto?i $\mathrm{d}=423369$ \& isNotice $=$ false \&instanceId=294\&rnum $=1$
[6] S. Kim and H. Wang, "From television to the film set: Korean drama Daejanggeum drives Chinese, Taiwanese, Japanese and Thai audiences to screen-tourism," International Communication Gazette, vol. 74, no. 5, pp. 423-442, 2012.

[7] A. Shani, Y. Wang, S. Hudson, and S. M. Gil, "Impacts of a historical film on the destination image of South America," Journal of Vacation Marketing, vol. 15, no. 3, pp. 229-242, 2009.

[8] S. Hudson and J. B. Ritchie, "Film tourism and destination marketing: The case of Captain Corelli's Mandolin," Journal of Vacation Marketing, vol. 12, no. 3, pp. 256-268, 2006.

[9] S. Beeton, Film-Induced Tourism, Channel View Publications, 2005.

[10] J. Connell, "Film tourism - Evolution, progress and prospects," Tourism Management, vol. 33, no. 5, pp. 1007-1029, 2012.

[11] N. Macionis and B. Sparks, "Film-induced tourism: An incidental experience," Tourism Review International, vol. 13, no. 2, pp. 93-101, 2009.

[12] N. Macionis, "Understanding the film-induced tourist," presented at the International tourism and media conference, Melbourne, Australia, Nov.24-26, 2004.

[13] R. Riley, D. Baker and C. S. V. Doren, "Movie induced tourism," Annals of Tourism Research, vol. 25, no. 4, pp. 919-935, 1998.

[14] N. Tooke and M. Baker, "Seeing is believing: The effect of film on visitor numbers to screened locations," Tourism Management, vol. 17, no. 2, pp. 87-94, 1996.

[15] J. Connell, "Toddlers, tourism and tobermory: Destination marketing issues and television-induced tourism," Tourism Management, vol. 26, no. 5, pp. 763-776, 2005

[16] A. F. Young and R. Young, "Measuring the effects of film and television on tourism to screen locations: A theoretical and empirical perspective," Journal of Travel \& Tourism Marketing, vol. 24, no. 2-3, pp. 195-212, 2008.

[17] B. Rittichainuwat and S. Rattanaphinanchai, "Applying a mixed method of quantitative and qualitative design in explaining the travel motivation of film tourists in visiting a film-shooting destination,' Tourism Management, vol. 46, pp. 136-147, 2015.

[18] M. Oppermann, "Tourism destination loyalty," Journal of Travel Research, vol. 39, no. 1, pp. 78-84, 2000.

[19] M. Li, L. A. Cai, X. Y. Lehto and J. Huang, "A missing link in understanding revisit intention - The role of motivation and image," Journal of Travel \& Tourism Marketing, vol. 27, no. 4, pp. 335-348, 2010.

[20] S. Shoemaker and R. C. Lewis, "Customer loyalty: The future of hospitality marketing," International Journal of Hospitality Management, vol. 18, no. 4, pp. 345-370, 1999.

[21] G. Prayag and C. Ryan, “Antecedents of tourists' loyalty to Mauritius: The role and influence of destination image, place attachment, personal involvement, and satisfaction," Journal of Travel Research, vol. 51, no. 3, pp. 342-356, 2012.

[22] H. Zhang, X. Fu, L. A. Cai, and L. Lu, "Destination image and tourist loyalty: A meta-analysis," Tourism Management, vol. 40, pp. 213-223, 2014.

[23] S. Baloglu and K. W. McCleary, "A model of destination image formation," Annals of Tourism Research, vol. 26, no. 4, pp. 868-897, 1999.

[24] A. Beerli and J. D. Martín, "Factors influencing destination image," Annals of Tourism Research, vol. 31, no. 3, pp. 657-681, 2004.

[25] A. D. Tasci and W. C. Gartner, "Destination image and its functional relationships," Journal of Travel Research, vol. 45, no. 4, pp. 413-425, 2007.

[26] S. Baloglu and D. Brinberg, "Affective images of tourism destinations," Journal of Travel Research, vol. 35, no. 4, pp. 11-15, 1997.

[27] G. M. Dann, "Tourists' images of a destination-an alternative analysis," Journal of Travel \& Tourism Marketing, vol. 5, no. 1-2, pp. 41-55, 1996.

[28] W. C. Gartner, "Image formation process," Journal of Travel \& Tourism Marketing, vol. 2, no. 2-3, pp. 191-216, 1994.

[29] H. Kim and S. L. Richardson, "Motion picture impacts on destination images," Annals of Tourism Research, vol. 30, no. 1, pp. 216-237, 2003.

[30] L. C. Manzo, "Beyond house and haven: Toward a revisioning of emotional relationships with places," Journal of Environmental Psychology, vol. 23, no. 1, pp. 47-61, 2003.

[31] D. R. Williams, M. E. Patterson, J. W. Roggenbuck, and A. E. Watson, "Beyond the commodity metaphor: Examining emotional and symbolic attachment to place," Leisure Sciences, vol. 14, no. 1, pp. 29-46, 1992. 
[32] G. Kyle, A. Graefe, and R. Manning, "Testing the dimensionality of place attachment in recreational settings," Environment and Behavior, vol. 37, no. 2, pp. 153-177, 2005.

[33] H. Ramkissoon, L. D. G. Smith, and B. Weiler, "Testing the dimensionality of place attachment and its relationships with place satisfaction and pro-environmental behaviours: A structural equation modelling approach," Tourism Management, vol. 36, pp. 552-566, 2013.

[34] C. Ryan, Researching Tourist Satisfaction: Issues, Concepts, Problems, New York: Routledge, 1995

[35] H. K. Hunt, Conceptualization and Measurement of Consumer Satisfaction and Dissatisfaction, Cambridge, MA: Marketing Science Institute, 1977.

[36] A. Yüksel and F. Yüksel, "The expectancy-disconfirmation paradigm: A critique," Journal of Hospitality \& Tourism Research, vol. 25, no. 2, pp. 107-131, 2001.

[37] S. Pike and C. Ryan, "Destination positioning analysis through a comparison of cognitive, affective, and conative perceptions," Journal of Travel Research, vol. 42, no. 4, pp. 333-342, 2004.

[38] S. Lee, S. Jeon and D. Kim, "The impact of tour quality and tourist satisfaction on tourist loyalty: The case of Chinese tourists in Korea," Tourism Management, vol. 32, no. 5, pp. 1115-1124, 2011.

[39] R. W. Brislin, "Back-translation for cross-cultural research," Journal of Cross-Cultural Psychology, vol. 1, no. 3, pp. 185-216, 1970.

[40] L. T. Hu and P. M. Bentler, "Cutoff criteria for fit indexes in covariance structure analysis: Conventional criteria versus new alternatives," Structural Equation Modeling: A Multidisciplinary Journal, vol. 6, no. 1, pp. 1-55, 1999.

[41] R. P. Bagozzi and Y. Yi, "On the evaluation of structural equation models," Journal of the Academy of Marketing Science, vol. 16, no. 1, pp. 74-94, 1988.

[42] J. F. Hair, W. C. Black, B. J. Babin and R. E. Anderson, Multivariate Data Analysis, 7th ed. Englewood Cliffs, NJ: Prentice-Hall, 2010.
[43] C. Fornell and D. F. Larcker, "Evaluating structural equation models with unobservable variables and measurement error," Journal of Marketing Research, vol. 18, no. 1, pp. 39-50, 1981.

[44] J. Pallant, SPSS Survival Manual: A Step by Step Guide to Data Analysis Using SPSS, 4th ed. New York: McGraw-Hill, 2010.

[45] Korea Tourism Organization. (2013). Hallyu Wave and Tourism. [Online]. Available: http://www.aianta.org/uploads/FileLinks/d31c5344f48d4b35a8efd1a2 8e49c9c1/WTC2013_KoreanPopCulture_CharmLee_1.pdf

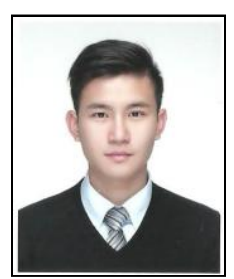

Weisheng Chiu is a current $\mathrm{PhD}$ candidate in the sport management program at Yonsei University. He also earned a MEd through Graduate Institute of Sport and Leisure Management from National Taiwan Normal University. He has published papers in English, Mandarin and Korean and presented his researches through journals and international conferences. His primary research interests include consumer behavior in sport and hospitality and marketing issues in sport and tourism industry.

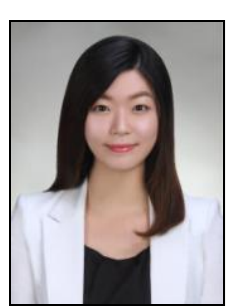

Shiheng Zeng is a graduate student majoring in sport and leisure studies and a research assistant in the International Program of Leisure \& Recreation Management at Yonsei University, Seoul, Korea. Her research interests include tourist behavior and tourism destination marketing. 